\title{
Temporal and spatial variability of the cropping limit in South Australia
}

\author{
Carly R. Tozer*, Danielle C. Verdon-Kidd, Anthony S. Kiem
}

Environmental and Climate Change Research Group, School of Environmental and Life Sciences, Faculty of Science and Information Technology, University of Newcastle, Callaghan, New South Wales 2308, Australia

\begin{abstract}
Since its establishment in 1865, Goyder's Line in South Australia has represented the division between land suitable for cropping and land seen as viable for grazing. Despite this, current cropping areas extend beyond Goyder's Line. In this study, the $220 \mathrm{~mm}$ growing season (April to October) rainfall isohyet is used as a proxy for Goyder's Line to assess its temporal and spatial variability. Using indices of the El Niño Southern Oscillation, Indian Ocean sea surface temperature variability, Southern Annular Mode and subtropical ridge, it is shown that climate state significantly influences the location of the $220 \mathrm{~mm}$ growing season rainfall isohyet. This implies that the boundary between viable and non-viable cropping areas (i.e. Goyder's Line or 'nature's limit') is non-stationary. These results also indicate the key influences on South Australia's climate and have important implications globally for agricultural practices operating in or bordering semi-arid environments.
\end{abstract}

KEY WORDS: Goyder's Line $\cdot$ Climate variability $\cdot$ Non-stationarity $\cdot$ Agricultural boundary

\section{INTRODUCTION}

'Rain follows the plow' was a theory that encouraged agricultural settlement in dryland areas in both the United States and Australia during the mid1800s. Supporters of the theory believed that humans could master nature and alter the climate through cultivation of the soil (Ferrill 1980). An opponent of this theory was George W. Goyder, who used vegetation in South Australia (SA) as an indicator to mark out the extent of the State's severe 1865 drought, effectively establishing 'nature's limit' to reliable agriculture in SA (Meinig 1961, Ferrill 1980, Whitelock 1985). This limit became known as Goyder's Line, and demarked the boundary between land suitable for agricultural pursuits to the south and less suitable land in the State's arid north (Meinig 1961). However, when above-average rain fell in the 1870 s, Goyder's Line did not halt agricultural expansion north. Indeed, supporters of the 'rain follows the plow' theory were buoyed by the sight of crops growing in areas that Goyder's Line had indicated to be too arid for agriculture and, hence, the agricultural frontier pushed north (Ferrill 1980). By the early 1880s, however, those that ventured north were reminded of 'nature's limit' when severe drought once again hit the State. In response, Goyder's Line was promptly resurrected to guide agricultural activity in SA.

While there is only one documented location of Goyder's Line, the history of the development, abandonment and then resurrection of the line suggests that the agricultural boundary of SA shifts on an interannual basis. Current cropping areas extend beyond the line (Nidumolu et al. 2012), which gives more weight to this idea. This raises the question of whether the apparent interannual variability in Goyder's Line has a coherent pattern and whether this pattern is related to atmospheric- and oceanic-based climate drivers (e.g. El Niño Southern Oscillation, ENSO). Therefore, the aim of this paper was to determine if Goyder's Line (i.e. nature's limit) shifts according to phases of known drivers of Australia's climate (e.g. Gallant et al. 2012, Murphy \& Timbal 2008). Identification (and then forecasting) of climate phases in which the risk of not 
receiving adequate growing season rainfall (GSR) is high (or low) may ultimately assist rainfall-dependent sectors (e.g. farmers) in managing their risk.

\section{DATA AND METHODS}

\subsection{Suitable proxy for Goyder's Line}

Goyder used vegetation to mark the original Goyder's Line but in the absence of annual vegetation data for SA, a proxy is required. Nidumolu et al. (2012) considered pre-European vegetation, the current extent of cropping, soil type, the $220 \mathrm{~mm}$ GSR isohyet, the $300 \mathrm{~mm}$ annual rainfall isohyet, simulated wheat yield and an isopleth of the 0.26 precipitation to evaporation (P:E) ratio but could not identify a consistent match with Goyder's Line. However, the isopleth of the 0.26 P:E ratio and the $220 \mathrm{~mm}$ GSR isohyet were both found to reasonably approximate Goyder's Line for most of the State (Nidumolu et al. 2012). A key aspect of this research is the analysis of long-term climate variability and patterns; given that evaporation data in Australia prior to 1970 are unreliable (Nidumolu et al. 2012) and that Australia has a relatively long record of rainfall data ( 100 yr), the $220 \mathrm{~mm}$ GSR isohyet was selected in our study as a proxy for Goyder's Line.

As seen in Fig. 1, Goyder's Line underestimates the current cropping boundary in the eastern Eyre Peninsula and Murray Mallee region. However, it is still a remarkable approximation of the cropping boundary, particularly given the limited data Goyder had at his disposal in 1865 (Nidumolu et al. 2012). The $220 \mathrm{~mm}$ GSR isohyet underestimates the current cropping boundary in the Murray Mallee region. The edge of cropping in this region is bounded by the River Murray (Fig. 1). Despite this, the 220 mm GSR isohyet provides a reasonable approximation of the cropping boundary for a statewide analysis.

High-resolution gridded rainfall data $\left(0.05 \times 0.05^{\circ}\right.$ grid cell size) from the Australian Water Availability Project (AWAP) (Jones et al. 2009) were used to calculate the average location of the $220 \mathrm{~mm}$ GSR isohyet (Fig. 1). Given that gridded data were inherently 'smoothed' and may not capture the temporal and spatial variability of rainfall (Ensor \& Robeson 2008, Tozer et al. 2012, King et al. 2013a) - a crucial aspect to this study — rainfall data from 9 Australian Bureau of Meteorology observation gauges were also analysed (Fig. 1). Based on the availability of gauged data, all analyses commence from 1918 and cease in 2011, providing 94 yr of continuous data.

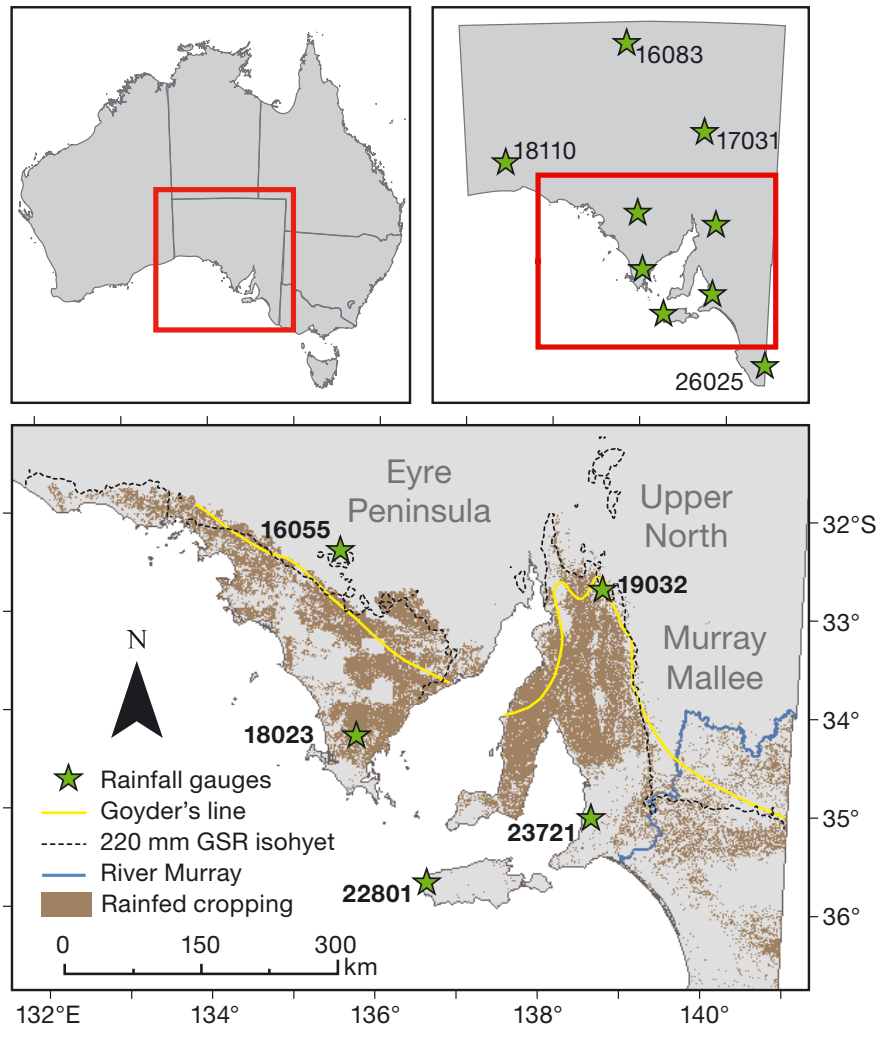

Fig. 1. Locations of Goyder's Line, the $220 \mathrm{~mm}$ growing season rainfall (GSR) isohyet (created using Australian Water Availability Project data, 1918-2011 average), rainfed cropping areas (Lymburner et al. 2010), the River Murray and 9 rainfall gauges used in the analysis

\subsection{Climate drivers}

Climate drivers selected for analysis were ENSO, Indian Ocean sea surface temperatures (SSTs), Southern Annular Mode (SAM) and subtropical ridge intensity (STRI). These modes of variability have previously been recognised as playing a significant role in driving Australia's rainfall variability (e.g. Kiem \& Franks 2001, Verdon \& Franks 2005, Hendon et al. 2007, Risbey et al. 2009, Verdon-Kidd \& Kiem 2009a, Kiem \& Verdon-Kidd 2010, Timbal \& Drosdowsky 2013). ENSO is represented here by SST anomalies in the Niño3.4 region $\left(5^{\circ} \mathrm{S}\right.$ to $5^{\circ} \mathrm{N}$, $170^{\circ}$ to $\left.120^{\circ} \mathrm{W}\right)$. SST anomalies in the Indonesian region $\left(0^{\circ}\right.$ to $10^{\circ} \mathrm{S}, 120^{\circ}$ to $\left.130^{\circ} \mathrm{E}\right)$ were used to represent Indian Ocean variability. Verdon \& Franks (2005) referred to these Indonesian region SST anomalies as the Indonesian Index (I.I.) and showed that SST variability in this region alone, rather than the Indian Ocean Dipole, influences winter/spring climate in Australia. The monthly SST anomalies in 
the Nino3.4 and I.I. regions were calculated relative to a 1971-2000 base period using the extended reconstruction of global SST (ERSST) dataset (version 3b) (Smith et al. 2008). A combined SAM index was developed from existing datasets produced by Marshall (2003) (1957-2011) and Visbeck (2009) (1918-1956) as per the recommendations of Ho et al. (2012). The STRI is represented by the maxima in mean sea level pressure anomalies along a longitude band of $145^{\circ}$ to $150^{\circ} \mathrm{E}$ and a latitude band of $10^{\circ}$ to $44^{\circ} \mathrm{S}$ (Drosdowsky 2005, Timbal \& Drosdowsky 2013). As per the SST anomalies, STRI anomalies were calculated relative to a 1971-2000 base period to maintain consistency. An index of the position of the subtropical ridge was also investigated, but in line with results presented in Timbal \& Drosdowsky (2013), the intensity of the ridge was found to be a more important driver of rainfall variability in Australia and, hence, results of subtropical ridge position are not shown here.

\subsection{Climate indices for the growing season}

The monthly STRI and SAM indices were averaged across the April to October period to produce a growing season index value for each year. The Niño3.4 and I.I. indices were averaged over the period from June to October to correspond to the peak period in the annual cycle of these drivers (e.g. Murphy \& Timbal 2008, Risbey et al. 2009). The indices were then classified into positive, neutral and negative events based on a threshold of 0.5 multiplied by the standard deviation of each index. A year was classified as negative if the growing season index value was less than -0.5 SD and positive if the index value was above $0.5 \mathrm{SD}$. All other years were classified as neutral. This method is similar to that used in Kiem \& Franks (2001) and Verdon \& Franks (2005). Table 1 indicates the years stratified into each index phase. It is evident that the I.I. records far fewer positive events relative to negative events. This is a reflection of both the positive trend in

Table 1. Years stratified into each index phase. The total number of years in each phase is shown in parentheses. I.I.: Indonesian Index, SAM: Southern Annular Mode, STRI: subtropical ridge intensity

\begin{tabular}{|c|c|c|c|}
\hline \multirow[t]{2}{*}{ Index } & \multicolumn{3}{|c|}{ - Phase } \\
\hline & Positive & Neutral & Negative \\
\hline Nino3.4 & $\begin{array}{l}\text { 1930, 1940, 1941, 1951, 1953, } \\
\text { 1957, 1963, 1965, 1969, 1972, } \\
\text { 1977, 1982, 1986, 1987, 1991, } \\
\begin{array}{l}1994,1997,2002-2006,2009 \\
(23 \text { yr) }\end{array}\end{array}$ & $\begin{array}{l}\text { 1918-1921, 1923, 1925, } \\
\text { 1927-1929, 1931, 1932, 1934, } \\
\text { 1935, 1937, 1939, 1943, 1944, } \\
\text { 1952, 1958, 1960-1962, } \\
\text { 1966-1968, 1976, 1979-1981, } \\
\begin{array}{l}1983,1984,1990,1992,1993, \\
1995,1996,2001,2008,2011 \\
(39 y r)\end{array}\end{array}$ & $\begin{array}{l}\text { 1922, 1924, 1926, 1933, 1936, } \\
\text { 1938, 1942, 1945-1950, } \\
\text { 1954-1956, 1959, 1964, 1970, } \\
\text { 1971, 1973-1975, 1978, 1985, } \\
1988,1989,1998-2000,2007, \\
2010 \text { (32 yr) }\end{array}$ \\
\hline I.I. & 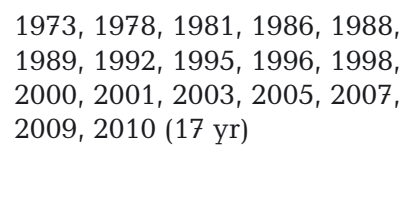 & $\begin{array}{l}1938,1942,1945,1950,1955, \\
1956,1958,1960,1962,1964, \\
1968,1970,1971,1974,1975, \\
1980,1983-1985,1990,1999, \\
2002,2004,2006,2008,2011 \\
(26 \text { yr })\end{array}$ & $\begin{array}{l}\text { 1918-1941, 1943, 1944, } \\
\text { 1946-1949, 1951-1954, 1957, } \\
\text { 1959, 1961, 1963, 1965-1967, } \\
\text { 1969, 1972, 1976, 1977, 1979, } \\
\text { 1982, 1987, 1991, 1993, 1994, } \\
1997 \text { (51 yr) }\end{array}$ \\
\hline SAM & $\begin{array}{l}1921,1922,1924,1927,1928, \\
1930-1934,1936-1938,1940, \\
1942,1943,1947,1949,1961, \\
1967,1976,1978,1979,1982, \\
1985,1989,1993,1997-1999, \\
2001,2003-2006,2008,2010 \\
(37 \mathrm{yr})\end{array}$ & $\begin{array}{l}\text { 1919, 1920, 1925, 1926, 1929, } \\
\text { 1935, 1939, 1950-1955, } \\
\text { 1958-1960, 1962, 1963, 1965, } \\
\text { 1966, 1969, 1973, 1983, 1984, } \\
\text { 1986, 1987, 1991, 1995, 1996, } \\
2000,2009,2011 \text { (32 yr) }\end{array}$ & $\begin{array}{l}\text { 1918, 1923, 1941, 1944, 1945, } \\
\text { 1946, 1948, 1956, 1957, 1964, } \\
\text { 1968, 1970-1972, 1974, 1975, } \\
1977,1980,1981,1988,1990 \\
1992,1994,2002,2007 \text { (25 yr) }\end{array}$ \\
\hline STRI & $\begin{array}{l}\text { 1919, 1940, 1941, 1944, 1949, } \\
\text { 1950, 1954, 1959, 1965, 1967, } \\
\text { 1969, 1972, 1982, 1987, 1993, } \\
\begin{array}{l}\text { 1994, 1997, 1999, 2006, } 2008 \\
(20 \mathrm{yr})\end{array}\end{array}$ & $\begin{array}{l}\text { 1918, 1921, 1927, 1930, 1933, } \\
\text { 1934, 1936-1939, 1945-1948, } \\
\text { 1957, 1961, 1963, 1966, 1973, } \\
1976,1977,1979,1980, \\
1983-1985,1988,1991,1992, \\
1995,1998,2000-2005,2007, \\
2010,2011(40 \mathrm{yr})\end{array}$ & $\begin{array}{l}1920,1922-1926,1928,1929, \\
1931,1932,1935,1942,1943, \\
1951-1953,1955,1956,1958, \\
1960,1962,1964,1968,1970, \\
1971,1974,1975,1978,1981, \\
1986,1989,1990,1996,2009 \\
(34 \text { yr })\end{array}$ \\
\hline
\end{tabular}


SSTs in the Indian Ocean (e.g. Alory et al. 2007) and the use of a recent anomaly period to calculate the indices. Interestingly, there was a large gap (1920-1939) between the first and second recorded positive phases of the STRI, and this coincided with a period of consistent I.I. negative events, i.e. pre-1940 a positive STRI rarely occurred with a negative I.I. event. Furthermore, very few SAM negative phases are recorded prior to 1940 . There is reasonable overlap (10 yr) between the STRI positive and Niño3.4 positive (indicative of an El Niño event) phases and the STRI negative and Niño3.4 negative (La Niña) phases (13 yr). There is also reasonable overlap (14 yr) between El Niño and I.I. negative years. The overlap between La Niña and I.I. positive years is not as pronounced; however, the first I.I. positive phase (1973) coincides with a La Niña year, as does the year 2010. Both of these years are associated with periods of extreme high rainfall across Australia (King et al. 2013b).

\section{RESULTS}

\subsection{Establishing the relationship between climate drivers and GSR}

The ratio of mean GSR occurring in the negative phase of each index to mean GSR in the positive phase is shown for each gauge in Table 2. The Student's $t$-test is used to determine the statistical significance of the difference between rainfall distributed in the 2 extreme phases of each driver.

The results for the ENSO analysis reveal that when SSTs in the Niño3.4 region are below average

Table 2. Ratio of average growing season rainfall recorded at each gauge during the 2 extreme phases for each index (negative:positive). Bold: significant at the 95th percentile. I.I.: Indonesian Index, SAM: Southern Annular Mode, STRI: subtropical ridge intensity

\begin{tabular}{|llllll|}
\hline \multirow{2}{*}{$\begin{array}{l}\text { Gauge } \\
\text { No. }\end{array}$} & \multirow{2}{*}{ Name } & \multicolumn{4}{c}{ Index } \\
\cline { 3 - 6 } & & Nino3.4 & I.I. & SAM & STRI \\
\hline 16055 & Yardea & 1.15 & $\mathbf{0 . 7 7}$ & 1.05 & $\mathbf{1 . 5 5}$ \\
16083 & Hamilton Station & $\mathbf{1 . 9 4}$ & $\mathbf{0 . 5 9}$ & 0.74 & $\mathbf{1 . 7 1}$ \\
17031 & Marree Comparison & 1.39 & $\mathbf{0 . 5 8}$ & 1.11 & $\mathbf{1 . 4 8}$ \\
18023 & Cummins & $\mathbf{1 . 1 7}$ & $\mathbf{0 . 8 8}$ & 1.06 & $\mathbf{1 . 5 3}$ \\
18110 & Cook & 1.32 & $\mathbf{0 . 6 7}$ & 0.97 & $\mathbf{1 . 3 5}$ \\
19032 & Orroroo & $\mathbf{1 . 2 0}$ & $\mathbf{0 . 7 8}$ & 1.10 & $\mathbf{1 . 6 2}$ \\
22801 & Cape Borda & $\mathbf{1 . 1 7}$ & 0.95 & 1.05 & $\mathbf{1 . 3 2}$ \\
& Comparison & & & & \\
23721 & Happy Valley & 1.11 & $\mathbf{0 . 7 7}$ & 1.08 & $\mathbf{1 . 4 2}$ \\
& Reservoir & & & & \\
26025 & Penola Post Office & $\mathbf{1 . 1 5}$ & $\mathbf{0 . 8 7}$ & $\mathbf{1 . 2 0}$ & $\mathbf{1 . 4 8}$ \\
\hline
\end{tabular}

(indicative of a La Niña event), GSR is higher relative to when SSTs are above average (El Niño event). For example, at gauge 16083, the GSR is nearly 2 times higher in a La Niña relative to an El Niño event. The results are significant at 5 of the 9 gauges. At all gauges, the results reveal that when SSTs in the Indonesian region are below average, GSR is lower relative to when SSTs are above average. These differences are significant at 8 out of the 9 stations. For the majority of the stations, a positive April to October SAM, which corresponds to a poleward shift in rain-bearing systems (Hendon et al. 2007, Gallant et al. 2012), is associated with lower GSR relative to a negative SAM. However, the differences between average rainfall distributed into each SAM phase are not as marked relative to the results shown for the other drivers. In fact, the result is only significant at gauge 26025, in the State's far southeast, which may be indicative of the impact zone of SAM. This is consistent with Risbey et al. (2009), who found that daily winter (June to August) rainfall in far southeastern SA was reduced in a positive SAM relative to a negative SAM, a result that was also significant at the 95th percentile. The STRI results show that when the subtropical ridge is more intense (i.e. pressure is greater than average), GSR is significantly reduced compared to when the STRI is below average. The difference between the 2 phases of the STRI is significant at all stations.

We conclude that a positive Niño3.4 phase (El Niño) and positive STRI (more intense subtropical ridge) is associated with decreased GSR in SA relative to a negative Niño3.4 (La Niña) and negative STRI (less intense subtropical ridge). A positive I.I. (above-average SSTs in the Indonesian region) is associated with above-average GSR in SA relative to a negative I.I.. These results are consistent with the findings of previous investigations into the relationship between Australian rainfall variability and these climate drivers (e.g. Verdon et al. 2004, Verdon \& Franks 2005, Larsen \& Nicholls 2009, Risbey et al. 2009, Timbal \& Drosdowsky 2013), which confirms that the indices utilised are representative of the physical processes likely to cause non-stationarity in Goyder's Line.

\subsection{Identifying variability in the location of Goyder's Line}

Fig. 2 shows the difference between the percent of time $220 \mathrm{~mm}$ GSR is recorded at each grid cell in a particular climate state (e.g. El Niño) and the percent 


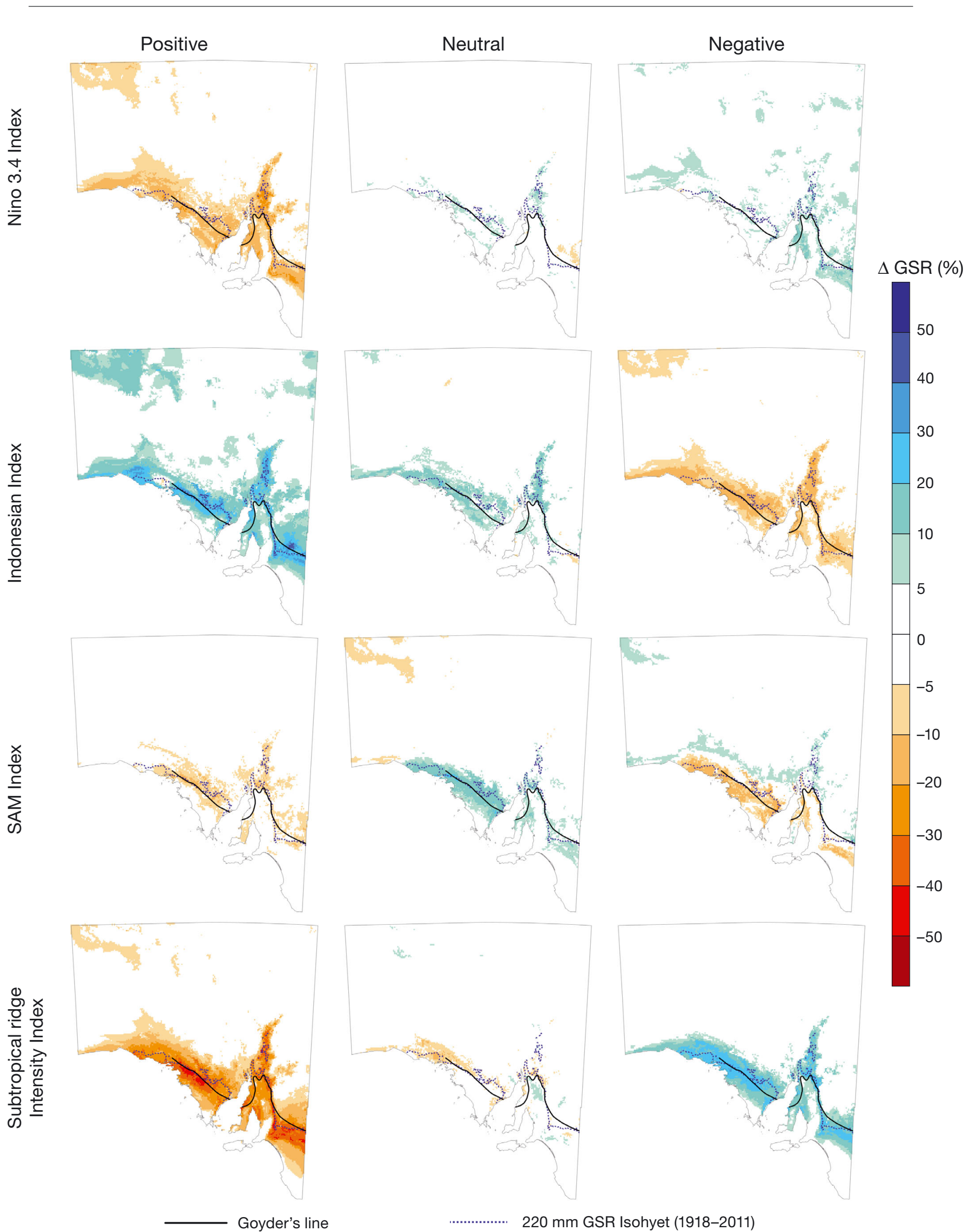

Fig. 2. Percentage difference between growing season rainfall (GSR) distributed in each index phase and average GSR (1918-2011) 
of time that each grid cell records $220 \mathrm{~mm}$ GSR for the whole record (1918-2011). For example, consider the gridded rainfall data extracted at gauge 19032, located in the small town of Orroroo, on Goyder's Line. On average, this location receives a GSR of $220 \mathrm{~mm}$ for $48.9 \%$ of the time (i.e. approximately half of the time). In an El Niño phase, it receives this amount $30.4 \%$ of the time. The difference, $-18.5 \%$, is shown in Fig. 2.

From these results, we are particularly interested to note when areas south of Goyder's Line (i.e. areas that, on average, are expected to receive adequate GSR) do not receive $220 \mathrm{~mm}$ GSR in a particular climate state. Conversely, we want to identify phases when areas north of Goyder's Line (i.e. areas that, on average, do not receive adequate GSR to allow for agricultural pursuits) receive $220 \mathrm{~mm}$ GSR more times than average.

The results in Fig. 2 show that north of Goyder's Line, $220 \mathrm{~mm}$ GSR is recorded up to $30 \%$ more often than average in an STRI negative phase or I.I. positive phase. During La Niña phases, $220 \mathrm{~mm}$ GSR is recorded up to $20 \%$ more than average. Conversely, during El Niño phases, areas south of Goyder's Line receive $220 \mathrm{~mm}$ GSR up to $30 \%$ less often compared to average. This result is even more extreme for the STRI positive phase, where the deficit between the percent of time $220 \mathrm{~mm}$ GSR is recorded in this phase relative to average extends far south of Goyder's Line. That is, when the STRI is more intense than usual, some areas south of Goyder's Line can expect to receive $220 \mathrm{~mm}$ GSR up to $50 \%$ less often compared to average.

The results, both in Table 2 and Fig. 2, suggest that there is not a strong relationship between SAM and GSR in SA, apart from far southeastern SA as previously mentioned. For the other 3 drivers, however, the results suggest that there is a relationship between climate phase and the percent of time adequate GSR is received in SA and that the boundary between viable and non-viable cropping shifts north and south depending on the phase of at least ENSO, I.I. and STRI.

\subsection{Relationship between the location of Goyder's Line and interactions between multiple climate drivers}

It is well know that climate drivers do not work independently; rather, they can act to enhance or dampen the impact generally associated with a single driver (e.g. Kiem et al. 2003, Risbey et al. 2009,
Verdon-Kidd \& Kiem 2009b, Kiem \& Verdon-Kidd 2010, Gallant et al. 2012). With this in mind, the years of analysis were further stratified into combined index phases (e.g. El Niño/STRI positive). ENSO in particular is acknowledged to exert an influence on other drivers (Risbey et al. 2009), and, furthermore, during El Niño (La Niña) events, the subtropical ridge is said to be stronger (weaker) (Drosdowsky 2005). In this context, one might therefore expect the combination of El Niño/STRI positive to result in (1) more areas (relative to the single driver results) south of Goyder's Line not receiving adequate GSR and (2) the difference between the number of times adequate GSR is recorded in the combined phase and average conditions to be larger relative to the single driver results. The opposite results could be expected for a La Niña/STRI negative combination.

Fig. 3 shows that the La Niña/STRI negative combination yields more extreme results relative to the single driver results. In this case, the area north of Goyder's Line that records $220 \mathrm{~mm}$ GSR more times than average is expanded. Interestingly, when El Niño years are combined with STRI negative years, the result is also wetter than average conditions. This may suggest that in SA, the STRI is more dominant than ENSO. The STRI positive and Niño3.4 neutral appears to be the 'driest' combination, again suggesting that the STRI is the dominant influence.

It is evident from these results that when the subtropical ridge is more intense, it is less likely (relative to average) that areas surrounding Goyder's Line (areas south of the line, in particular) will receive adequate GSR irrespective of the ENSO phase. The same conclusion was reached when analysing combinations of STRI and I.I. and STRI and SAM (not shown here). It may be no revelation, however, that the STRI appears to be the dominant driver relative to ENSO, Indian Ocean SSTs and SAM. Nicholls (2009) suggests that an index of a climate driver that includes surface pressure over Australia would, of course, be related to rainfall in Australia. Indices based on SSTs, on the other hand, are one physical step removed from rainfall (Risbey et al. 2009). Past studies have shown that the impact of Indian Ocean SST variability, SAM and ENSO on rainfall in Australia is conducted through the subtropical ridge (Larsen \& Nicholls 2009, Cai et al. 2011, Whan et al. 2014). Furthermore, Whan et al. (2014) show that in the austral winter, subtropical ridge variability appears to modulate the El Niño impact on rainfall in southeastern Australia. Hence, there is undoubted interplay between the subtropical ridge and other large-scale drivers. 


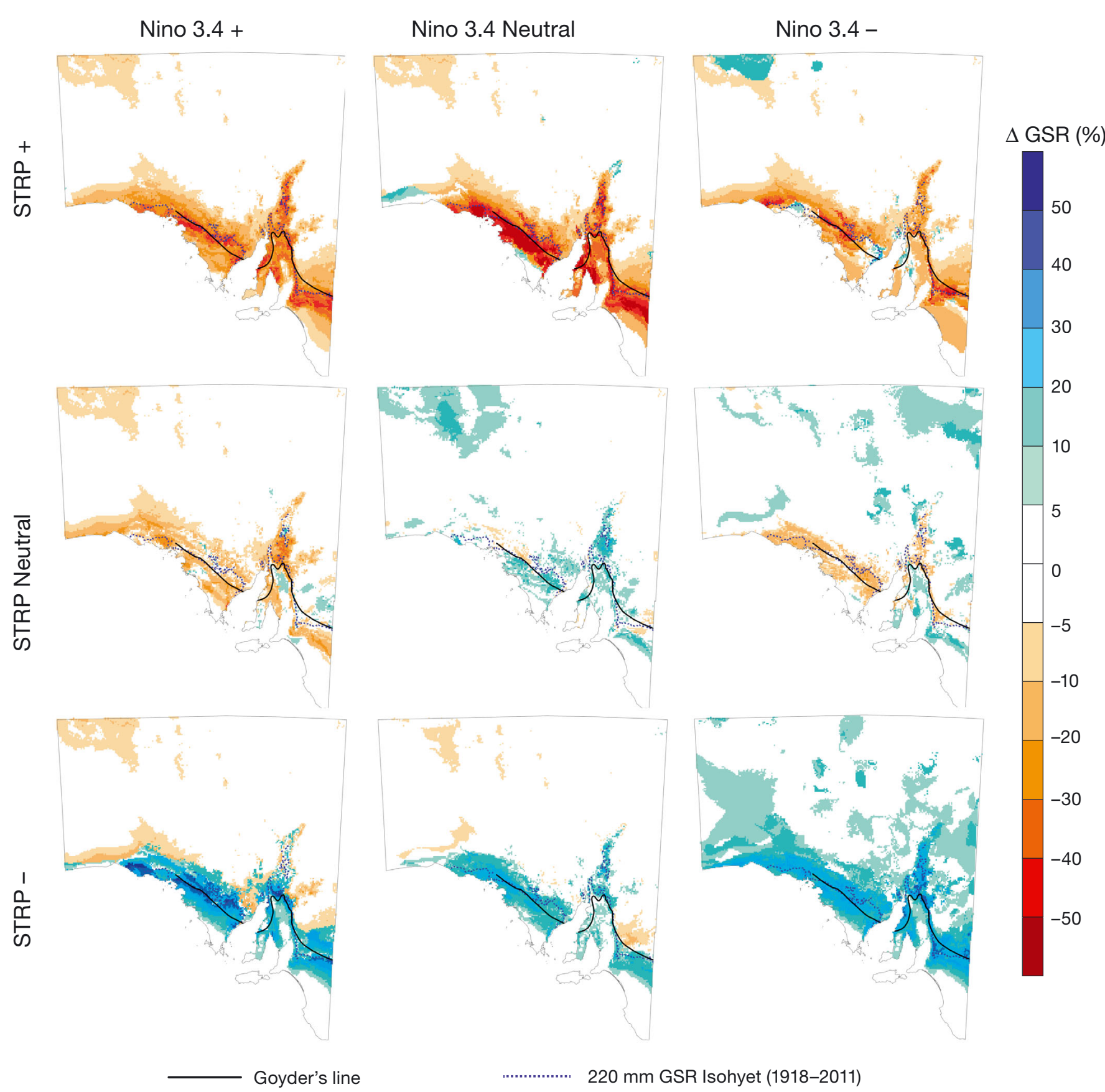

Fig. 3. Percentage difference between growing season rainfall (GSR) distributed in combined subtropical ridge intensity and Nino3.4 phases and average GSR (1918-2011). STRP: subtropical ridge

\subsection{Evidence of non-stationarity in Goyder's Zone from vegetation/Normalised Difference Vegetation Index}

Normalised Difference Vegetation Index (NDVI) maps were reviewed to ground truth the GSR and STRI/ENSO relationships identified in earlier sections. The NDVI represents the ratio between the red and near-infrared regions of the electromagnetic spectrum and can be used as an indicator of crop yield (Prasad et al. 2006). NDVI values will vary across crop type and throughout the growing season (Prasad et al. 2006, Wardlow \& Egbert 2008). In this case, NDVI values have been averaged across the growing season for the most recent years in which an El Niño/STRI positive phase (2006) and La Niña/ STRI negative phase (1989) occurred (Fig. 4). Increasing positive values of NDVI indicate increasing 


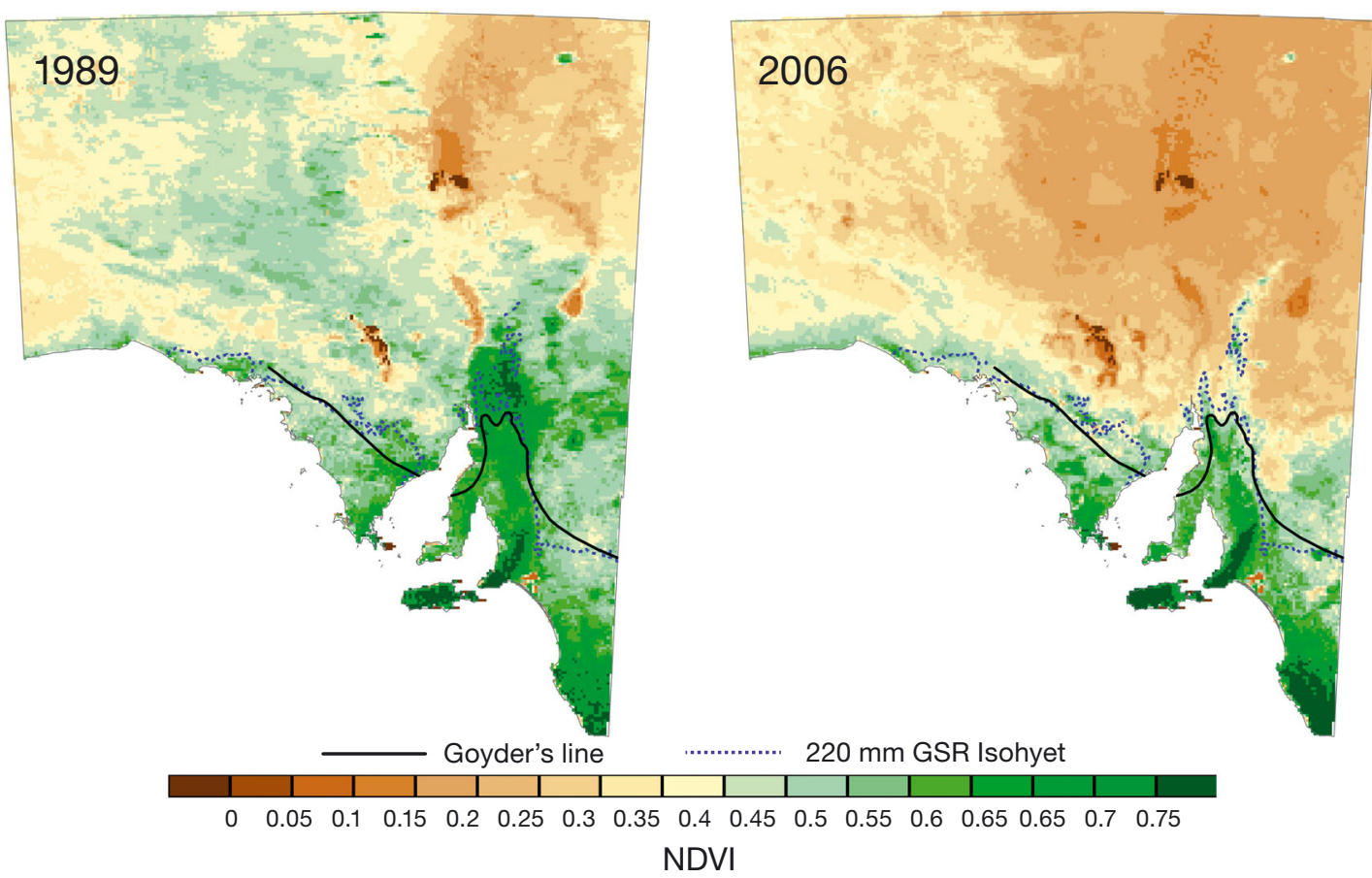

Fig. 4. National data vegetation index (NDVI) maps averaged over the growing season for 1989 (La Niña/subtropical ridge intensity [STRI] negative) and 2006 (El Niño/STRI positive)

amounts of healthy, green vegetation. While it is not possible from this broad-scale analysis to accurately differentiate agricultural areas from other vegetation types, it is very clear that there was a greater amount of vegetation in 1989 relative to 2006. Areas of healthy vegetation, which may indicate agricultural areas, appear to extend further north of Goyder's Line in 1989, complementing the results presented earlier based on GSR. These results provide 'onthe-ground' evidence of the variability of Goyder's Line relative to climate phase.

\subsection{Establishing Goyder's Zone}

What is clear from these results is that the agricultural boundary shifts depending on climate state. An area south of Goyder's Line may, on average, receive adequate GSR, but during a combined El Niño/STRI positive phase (for example), it is far less likely to receive adequate GSR. As such, we suggest that a zone, whereby the chance of areas within the zone receiving adequate GSR varies accord- ing to climate state, is a more appropriate way to characterize the agricultural boundary.

The average locations of the $220 \mathrm{~mm}$ isohyets for the extreme phases of ENSO and STRI (i.e. El Niño/ STRI positive and La Niña/STRI negative) are shown in Fig. 5. The La Niña/STRI negative combination isohyet is situated $50 \mathrm{~km}$ north of the average

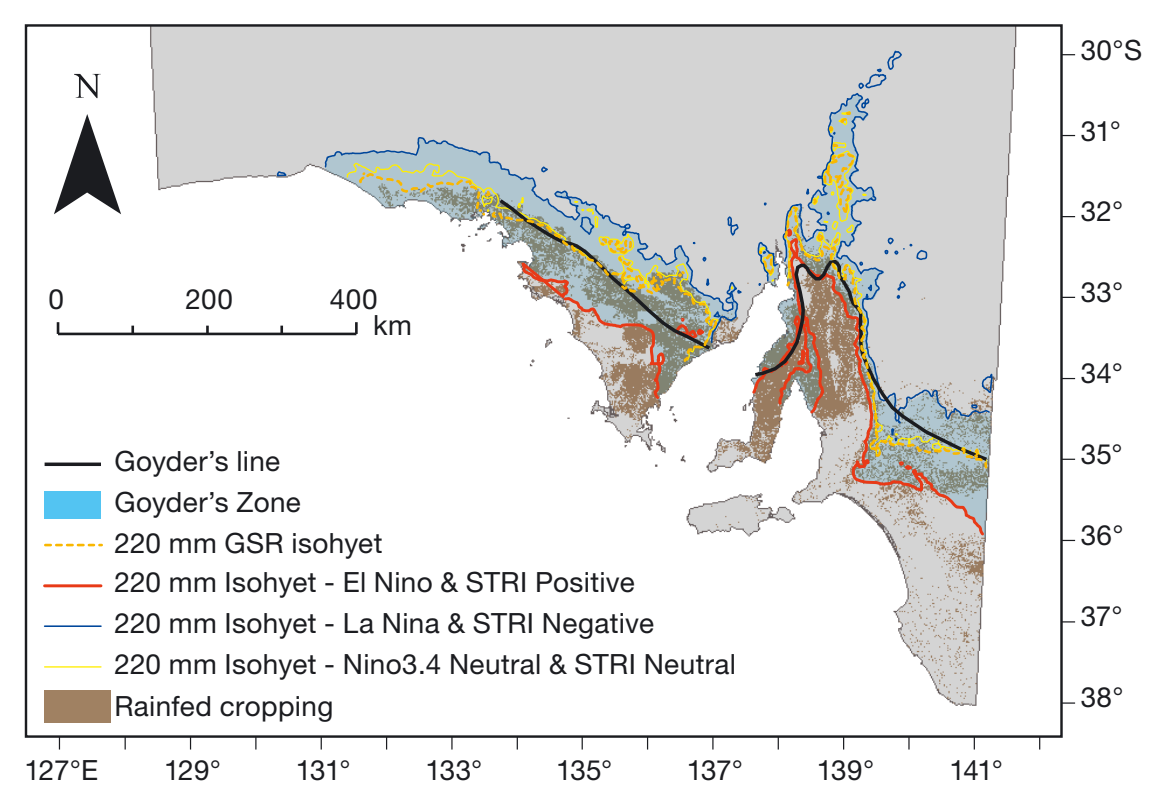

Fig. 5. Creation of Goyder's Zone based on the $220 \mathrm{~mm}$ isohyets for the extreme combined Nino3.4 and subtropical ridge intensity (STRI) index phases 
220 mm GSR isohyet, while the El Niño/STRI positive isohyet sits up to approximately $90 \mathrm{~km}$ south of the average isohyet. The $220 \mathrm{~mm}$ isohyet for the combined neutral phases of each index is also presented in Fig. 5. It is a close fit to the average (1918-2011) $220 \mathrm{~mm}$ GSR isohyet, as would be expected.

It is interesting to note from Fig. 5 that in the Murray Mallee region, the La Niña/STRI negative isohyet tracks the current cropping boundary. Given this and that, as mentioned previously, the average (19182011) $220 \mathrm{~mm}$ GSR isohyet underestimates the current cropping boundary in the Murray Mallee, cropping in this region could potentially extend further north of its current boundary. It is clear that the cropping boundary in this region is different than the rest of the State, perhaps because of the presence of a large water body (River Murray). Future analyses could investigate regional changes in the cropping boundary and seek out region-specific proxies of Goyder's Line.

The isohyets for the extreme phases can be thought of as the outer bounds of Goyder's Zone. That is, during a La Niña/STRI negative phase, those areas north of Goyder's Line (but south of the La Niña/STRI negative isohyet shown in Fig. 5) have a higher chance relative to average conditions of receiving adequate GSR for cropping. Conversely, during an El Niño/ STRI positive phase, areas south of Goyder's Line but north of the El Niño/STRI positive isohyet (i.e. areas that would normally receive adequate GSR) have an increased chance of not receiving adequate GSR.

\section{CONCLUSIONS}

This study investigates the variability of Goyder's Line, which has long represented the agricultural/ pastoral boundary in SA (Meinig 1961, Ferrill 1980, Whitelock 1985), relative to known climate drivers of Australia's rainfall variability. In doing so, we find the STRI to have a marked impact on GSR in SA and propose that a 'Goyder's Zone' would better account for the variability in the location of the agricultural boundary. The zone represents marginal cropping areas that will be more/less successful depending on climate state during a growing season.

Further, Nidumolu et al. (2012) found that in the future, because of human-induced climate change, SA's agricultural boundary will likely shift south. Given the key role the subtropical ridge plays in driving GSR variability in SA, our work complements this finding in that we may provide the physical mechanism as to why the boundary might move south (i.e. the suggested intensification of the subtropical ridge, Timbal \& Drosdowsky 2013).

The results of this study highlight the need for improved forecasts of all climate drivers. Even a perfect forecast of ENSO will not be helpful for SA without an understanding of what phase other drivers, in particular the STRI, are in. Indeed, the insights gained here can be utilised to better target seasonal forecasting models for SA.

Acknowledgements. C.R.T. is supported by the University of Newcastle Research Scholarship Scheme, a CSIRO Land and Water Flagship Scholarship and a NCCARF Water Network Scholarship. The authors thank O. Rey-Lescure (University of Newcastle) for providing the NDVI data, and B. Timbal (CAWCR) for supplying the subtropical ridge data. Thanks also to 2 anonymous reviewers, whose comments undoubtedly improved the quality of this paper.

\section{LITERATURE CITED}

Alory G, Wijffels S, Meyers G (2007) Observed temperature trends in the Indian Ocean over 1960-1999 and associated mechanisms. Geophys Res Lett 34, doi:10.1029/ 2006GL028044

Cai W, van Rensch R, Cowan T (2011) Influence of globalscale variability on the subtropical ridge over Southeast Australia. J Clim 24:6035-6053

> Drosdowsky W (2005) The latitude of the subtropical ridge over eastern Australia: the L index revisited. Int J Climatol 25:1291-1299

Ensor LA, Robeson SM (2008) Statistical characteristics of daily precipitation: comparisons of gridded and point datasets. J Appl Meteorol Climatol 47:2468-2476

Ferrill JW (1980) The marginal lands of Australia and the American west: some comparisons in their perceptions and settlement. In: Volgyes I, Lonsdale RE, Avery WP (eds) The process of rural transformation. Pergamon Press, New York, NY, p 68-88

Gallant AJE, Kiem AS, Verdon-Kidd DC, Stone RC, Karoly DJ (2012) Understanding hydroclimate processes in the Murray-Darling Basin for natural resources management. Hydrol Earth Syst Sci 16:2049-2068

> Hendon HH, Thompson DWJ, Wheeler MC (2007) Australian rainfall and surface temperature variations associated with the Southern Hemisphere Annular Mode. J Clim 20:2452-2467

> Ho M, Kiem AS, Verdon-Kidd DC (2012) The Southern Annular Mode: a comparison of indices. Hydrol Earth Syst Sci 16:967-982

Jones DA, Wang W, Fawcett R (2009) High-quality spatial climate analyses for Australia. Aust Meteorolog Oceanogr J 58:233-248

Kiem AS, Franks SW (2001) On the identification of ENSOinduces rainfall and runoff variability: a comparison of methods and indices. Hydrol Sci J 46:715-727

$>$ Kiem AS, Verdon-Kidd DC (2010) Towards understanding hydroclimatic change in Victoria, Australia - preliminary insights into the 'Big Dry'. Hydrol Earth Syst Sci 14: 433-445

> Kiem AS, Franks SW, Kuczera G (2003) Multi-decadal vari- 
ability of flood risk. Geophys Res Lett 30:1035, doi:10. 1029/2002GL015992

King AD, Alexander LV, Donat MG (2013a) The efficacy of using gridded data to examine extreme rainfall characteristics: a case study for Australia. Int J Climatol 33: 2376-2387, doi:10.1002/grl.50427

King AD, Alexander LV, Donat MG (2013b) Asymmetry in the response of eastern Australia extreme rainfall to lowfrequency Pacific variability. Geophys Res Lett 40: 2271-2277

Larsen SH, Nicholls N (2009) Southern Australian rainfall and the subtropical ridge: variations, interrelationships, and trends. Geophys Res Lett 36:L08708, doi:10.1029/ 2009GL037786

Lymburner L, Tan P, Mueller N, Thackway R and others (2010) 250 metre dynamic land cover dataset of Australia, 1st edn. Geoscience Australia, Canberra

- Marshall GJ (2003) Trends in the Southern Annular Mode from observations and reanalyses. J Clim 16:4134-4143

Meinig DW (1961) Goyder's line of rainfall: the role of a geographic concept in South Australian land policy and agricultural settlement. Agric Hist 35:207-214

Murphy BF, Timbal B (2008) A review of recent climate variability and climate change in southeastern Australia. Int J Climatol 28:859-879

Nicholls N (2009) Local and remote causes of the southern Australian autumn-winter rainfall decline, 1958-2007. Clim Dyn 34:835-845

Nidumolu UB, Hayman PT, Howden SM, Alexander BM (2012) Re-evaluating the margin of the South Australian grain belt in a changing climate. Clim Res 51:249-260

Prasad AK, Chai L, Singh RP, Kafatos M (2006) Crop yield estimation model for Iowa using remote sensing and surface parameters. Int J Appl Earth Obs Geoinf 8:26-33

Risbey JS, Pook MJ, McIntosh PC, Wheeler MC, Hendon $\mathrm{HH}$ (2009) On the remote drivers of rainfall variability in Australia. Mon Weather Rev 137:3233-3253

Smith TM, Reynolds RW, Peterson TC, Lawrimore J (2008)

Editorial responsibility: Gerrit Hoogenboom,

Prosser, Washington, USA
Improvements to NOAA's historical land-ocean surface temperature analysis (1880-2006). J Clim 21:2283-2296

Timbal B, Drosdowsky W (2013) The relationship between the decline of southeastern Australian rainfall and the strengthening of the subtropical ridge. Int J Climatol 33: 1021-1034

Tozer CR, Kiem AS, Verdon-Kidd DC (2012) On the uncertainties associated with using gridded rainfall data as a proxy for observed. Hydrol Earth Syst Sci 16:1481-1499

> Verdon DC, Franks SW (2005) Indian Ocean sea surface temperature variability and winter rainfall: eastern Australia. Water Resour Res 41:W09413, doi:10.1029/2004 WR003845

- Verdon DC, Wyatt AM, Kiem AS, Franks SW (2004) Multidecadal variability of rainfall and streamflow: eastern Australia. Water Resour Res 40:W10201, doi:10.1029/ 2004WR003234

> Verdon-Kidd DC, Kiem AS (2009a) Nature and causes of protracted droughts in southeast Australia: comparison between the Federation, WWII, and Big Dry droughts. Geophys Res Lett 36:L22707, doi:10.1029/2009GL041067

> Verdon-Kidd DC, Kiem AS (2009b) On the relationship between large-scale climate modes and regional synoptic patterns that drive Victorian rainfall. Hydrol Earth Syst Sci 13:467-476

Visbeck M (2009) A station-based Southern Annular Mode index from 1884 to 2005. J Clim 22:940-950

> Wardlow BD, Egbert SL (2008) Large-area crop mapping using time-series MODIS $250 \mathrm{~m}$ NDVI data: an assessment for the U.S. central Great Plains. Remote Sens Environ 112:1096-1116

Whan K, Timbal B, Lindesay J (2014) Linear and nonlinear statistical analysis of the impact of sub-tropical ridge intensity and position on south-east Australian rainfall. Int J Climatol 34:326-342

Whitelock D (1985) Conquest to conservation: history of human impact on the South Australian environment. Wakefield Press, Cowandilla

Submitted: July 18, 2013; Accepted: January 3, 2014 Proofs received from author(s): April 18, 2014 